\title{
Compositional, Functional and Pasting Properties of Composite Flour Fortified with Button Mushroom (Agaricus bisporus) Powder and Inulin
}

\author{
Abdellatief A. Sulieman ${ }^{1,2}$, Ke-Xue Zhu' ${ }^{1}$, Wei Peng ${ }^{1}$, Muhammad Shoaib ${ }^{1}$, \\ Hayat A. Hassan ${ }^{2}$, Hui-Ming Zhou ${ }^{1, *}$ \\ ${ }^{1}$ State Key Laboratory of Food Science and Technology, School of Food Science and Technology, Jiangnan University, \\ Wuxi, Jiangsu, PR China \\ ${ }^{2}$ Department of Cereal Science and Technology, National Food Research Center, Ministry of Higher Education and Scientific Research, \\ Khartoum North, Sudan \\ *Corresponding author: lotfiabba@yahoo.com; hmzhou@jiangnan.edu.cn
}

\begin{abstract}
Supplementation of composite gluten-free flour (CGFF) with functional food ingredients can be useful to improve its nutritional and health quality. In the present research, the chemical, functional, pasting, and syneresis characteristics of CGFF were studied. CGFF was prepared with different percentages of sweet potato flour (SPF), glutinous rice flour (GRF), button mushroom powder (BMP) and inulin. The xanthan gum (0.5 \%) was added as a constant ingredient for all the blends. Addition of BMP to SPF-GRF increased ash (from 1.23 to $2.34 \mathrm{~g} / 100 \mathrm{~g}$ ), protein (from 5.24 to $11.74 \mathrm{~g} / 100 \mathrm{~g}$ ), fat (from 0.15 to $0.93 \mathrm{~g} / 100 \mathrm{~g}$ ), energy (from 345.71 to $350.77 \mathrm{kcal} / 100 \mathrm{~g}$ ), and total dietary fibers (from 3.97 to $8.61 \mathrm{~g} / 100 \mathrm{~g}$ ) contents, while contents of moisture and carbohydrate decreased (from 12.53 to $11.13 \mathrm{~g} / 100 \mathrm{~g}$ and 80.85 to $73.86 \mathrm{~g} / 100 \mathrm{~g}$ ), respectively. On the other hand, fortification of inulin led to reduces in moisture (from 12.53 to $11.07 \mathrm{~g} / 100 \mathrm{~g}$ ) and ash (from 1.23 to $0.11 \mathrm{~g} / 100 \mathrm{~g}$ ) contents, whereas carbohydrate, energy, and soluble dietary fibers increased (from 80.85 to $83.54 \mathrm{~g} / 100 \mathrm{~g}, 345.71$ to $355.93 \mathrm{kcal} / 100 \mathrm{~g}$ and 1.22 to $1.77 \mathrm{~g} / 100 \mathrm{~g})$, respectively. Essential and non-essential amino acids of samples containing BMP were higher than samples containing inulin. Moreover, supplementation of BMP increased macro, and micro-minerals, such as $\mathrm{K}, \mathrm{Ca}, \mathrm{Mg}, \mathrm{P}, \mathrm{Fe}$ and $\mathrm{Cu}$, respectively. Water and oil absorption indexes, and solubility were improved as a result of BMP inclusion, while swelling power increased, and viscosity and syneresis of CGFF decreased with incorporation of inulin. It can be concluded that the incorporation of BMP and inulin improved the nutritional, functional, and syneresis properties of SPF-GRF, which can be utilized in the functional bakery products.
\end{abstract}

Keywords: composite gluten-free flour, button mushroom, dietary fiber, amino acids, functional properties, mineral elements, inulin

Cite This Article: Abdellatief A. Sulieman, Ke-Xue Zhu, Wei Peng, Muhammad Shoaib, Hayat A. Hassan, and Hui-Ming Zhou, "Compositional, Functional and Pasting Properties of Composite Flour Fortified with Button Mushroom (Agaricus bisporus) Powder and Inulin.” Journal of Food and Nutrition Research, vol. 5, no. 8 (2017): 614-621. doi: 10.12691/jfnr-5-8-12.

\section{Introduction}

Quality evaluation of flour and composite flour involves the application of physicochemical and sensorial tests based on the chemical composition, gelatinization temperature, baking quality, and physical properties of baked product. Interpreting the chemical, functional and, pasting characteristics of the flour and the blends would facilitate the understanding of their potential uses and applications.

Many gluten-free flour products have poor nutritional value in terms of proteins, dietary fibers, and minerals because they consisting mainly of carbohydrates [1]. Therefore, supplementation of these flours with functional food ingredients is an increasing trend to improve their nutritional and health quality. Composite flour is defined as a mixture of different flours rich in starch, protein, and other nutrients with or without the addition of wheat flour [2]. Composite flours have been used extensively and successfully in many developing countries in the production of baked foods. In this work, the use of composite flour was to enhance the nutritional and health characteristics of the baked products for celiac disorder patients. Sweet potato flour (SPF), glutinous rice flour (GRF), mushroom powder and inulin can be used to develop composite gluten-free bread to enhance their proteins, dietary fibers, and minerals $[3,4,5]$. SPF has been applied to improve the flavor and texture of cookies and could significantly enhance the dietary fiber and mineral contents of the product [6]. Mushroom powder is a good supplement for sweet potato-based baked products due to both mushroom powder and SPF are complementary in 
protein and other nutrients. SPF is a poor in protein, whereas mushroom powder possesses high protein with an important content of essential amino acids. Additionally, mushrooms contain significant amount of minerals such as potassium, phosphorus, calcium, and iron [7], besides have good level of dietary fibers due to the presence of non-starch polysaccharides. Genetic structure and environmental factors are mainly responsible for the variations in the composition of the sweet potato and rice, as well as the substrate compositions are affecting mushroom chemical composition.

Button mushroom (Agaricus bisporus), the most cultivated and consumed mushroom worldwide, with a high nutritional value among different varieties, and it contributes around $40 \%$ of the total world mushroom production [4]. Inulin is a mixture of polysaccharides and prebiotic, and it plays important role in the nutritional and technological fields. Furthermore, inulin based functional products have good acceptance in the international markets, these products offer additional benefits in terms of natural prebiotic, dietary fiber, texture modifier, fat or sugar replacer, and stabilizer [8,9]. Functional and pasting properties are necessary to evaluate and possibly assist to predict how new nutrient may behave in specific systems, in addition to demonstrate whether or not such nutrient can be used to stimulate or replace convectional nutrient $[10,11]$. The aim of this work was to assess the effect of sweet potato flour (SPF), glutinous rice flour (GRF), button mushroom powder (BMP) and inulin on chemical, functional, pasting and syneresis characteristics of enriched composite gluten-free flour, as well as its suitability for baking process.

\section{Materials and Methods}

\subsection{Materials}

Sweet potato roots (white variety) and glutinous rice flour were purchased from supermarket in Wuxi, China. Freeze-dried button mushroom powder (from Longhai Union Food Co., Ltd., Zhangzhou, Fujian, China); inulin (average degree of polymerization, DP > 10\%) (from Guangzhou Zeyu Biotechnology Co., Ltd., China) and xanthan gum (from Danisco Co.).

\subsection{Sweet Potato Flour Production}

Sweet potato roots were sorted, peeled, washed and sliced. The slices were blanched at $60^{\circ} \mathrm{C}$ for $10 \mathrm{~min}$, dried at $60^{\circ} \mathrm{C}$ for $10 \mathrm{~h}$ in convection oven (Dasol Scientific Co. Ltd., Seoul, Korea), and then milled by using laboratory scale mill (Tianjin, Taisite, Instrument Co., Ltd., Tianjin, China). The flour was sieved through an 80-mesh sieve, packed and finally sealed in bags for further analysis.

\subsection{Composite Flour Preparation}

Three blends were prepared by mixing sweet potato flour (SPF), glutinous rice flour (GRF), fortified with button mushroom (Agaricus bisporus) powder (BMP) and the same fortified with different percentages of inulin (86.5:10:3, 83.5:10:6, and 80.5:10:9). Which were referred to the treatments $\left(\mathrm{T}_{1}, \mathrm{~T}_{2}\right.$ and $\left.\mathrm{T}_{3}\right)$. Sweet potato flour (89.5\%) with glutinous rice flour $(10 \%)$ was used as control. Xanthan gum was added to all flour blends at $0.5 \%$ by the total weight. The composite gluten-free flour was stored in air tight polyethylene bags for analysis.

\subsection{Chemical Analyzes}

\subsubsection{Proximate Composition}

The moisture, ash, protein and fat contents of the samples were determined according to the method of AOAC [12]. The protein content was measured as total nitrogen content by Kjeldahl procedure using a protein factor of 4.38 for BMP and 6.25 for other samples; crude fat of a known weight of sample was extracted with hexane using a Soxhlet apparatus. Carbohydrate content was obtained by difference from moisture, ash, protein and fat. Energy was calculated according to the equation: Energy $(\mathrm{kcal} / 100 \mathrm{~g})=4 \times(\mathrm{g}$ proteins $+\mathrm{g}$ carbohydrates $)+$ $9 \times$ (g fat). Dietary fibers were determined using enzymatic-gravimetric methods according to description of Latimer [13]. All experiments were performed in triplicate.

\subsubsection{Amino Acids Composition}

Amino acids composition of samples was carried out using a high performance liquid chromatography (HPLC) in an Agilent 1100 (Agilent Technologies, Palo Alto, CA, USA) assembly system with UV detector operated at 338 $\mathrm{nm}$. Amino acids were analyzed according to the method described by Huang et al. [14] with some modifications. $1.0 \mathrm{~g}$ of sample was dissolved in $20 \mathrm{~mL}$ of $6 \mathrm{~N} \mathrm{HCL}$ and poured into a hydrolysis tube with screw cap and then hydrolyzed for $22 \mathrm{~h}$ under a nitrogen atmosphere. The extracted sample was dissolved in $4.8 \mathrm{~mL} 10 \mathrm{M} \mathrm{NaOH}$ to neutralize for acid hydrolysis. After dilution to a known volume and filtration, the hydrolysate $(1.0 \mu \mathrm{L})$ was injected into HPLC column.

\subsubsection{Mineral Composition}

Mineral composition of sample was analyzed using a wet digestion with closed system according to the method of AOAC [15]. Dried sample (1.0 g) was digested with concentrated $\mathrm{HNO}_{3}(5 \mathrm{~mL})$ and $\mathrm{HCLO}_{4}(1.0 \mathrm{~mL})$ in an oven at $100{ }^{\circ} \mathrm{C}$ for $6 \mathrm{~h}$. The digested samples were transferred to volumetric flask (100 mL), diluted, filtered through Whatman filter paper No. 541 and then transferred to plastic bottles (50 mL) for mineral detection using atomic absorption spectrophotometer.

\subsection{Functional Properties}

Bulk density was determined according to [16] with slight modifications. Flour sample (10 g) was measured in a graduated cylinder $(25 \mathrm{~mL})$ after tapping the cylinder on a laboratory bench several times until no visible decrease in volume was noticed. The bulk density based on the weight (g) and volume (mL) was calculated.

$$
\text { Bulk density }(\mathrm{g} / \mathrm{ml})=\frac{\text { Weight of sample }}{\text { Volume of sample after tapping }} \text {. }
$$


Water absorption index was measured by the method of [17]. $1.0 \mathrm{~g}$ of sample was mixed with $15 \mathrm{~mL}$ of distilled water in a $25 \mathrm{~mL}$ centrifuge tube and agitated on a vortex mixer for $2 \mathrm{~min}$, and then centrifuged at $4000 \mathrm{rpm}$ for 20 minutes. The supernatant was decanted and discarded. The adhering drops of water were removed and the tube reweighed again.

$$
\text { WAI }(\mathrm{g} / \mathrm{g})=\frac{\left[\begin{array}{l}
(\text { Weight tube }+ \text { sediment }) \\
- \text { weight of empty tube }
\end{array}\right]}{\text { Weight of sample }} \text {. }
$$

Oil absorption index was determined by the method of [18] with minor modifications, to $1.0 \mathrm{~g}$ of flour, $10 \mathrm{~mL}$ of sunflower oil was added in a plastic centrifuge tube (25 mL) and allowed to stand at room temperature for 30 min, and then centrifuged for $20 \mathrm{~min}$ at $4000 \mathrm{rpm}$. Oil absorption was examined as gram oil bound per gram flour.

Swelling power and solubility were determined according to the method described by Crosbie [19] with slight modifications. A $15.0 \mathrm{~mL}$ of distilled water was added to $0.5 \mathrm{~g}$ of flour sample in centrifuge tube, and heated in a water bath at $95^{\circ} \mathrm{C}$ for $30 \mathrm{~min}$, with constant stirring. The resulting slurry was cooled to room temperature and centrifuged at $4000 \mathrm{rpm}$ for $15 \mathrm{~min}$. The supernatant was decanted into an evaporating dish, dried in an oven at $105^{\circ} \mathrm{C}$ for $4 \mathrm{~h}$. The dried supernatant and the sediment were weighed. The percentage of solubility (S\%) and swelling power (SP g/g) on dry basis was calculated as follows:

$$
\begin{aligned}
& \text { Swelling power }(\mathrm{SP} g / \mathrm{g}) \\
& =(\text { sediment weight } \times 100) /(\text { dry sample weight }) \\
& \quad \times(100-\mathrm{S} \%) \text {. } \\
& \text { Solubility }(\mathrm{S} \%)=\frac{\text { dry supernatant weight }}{\text { weight of dry sample }} \times 100 \% \text {. }
\end{aligned}
$$

\subsection{Pasting Properties}

Pasting characteristics of flours and the blends were measured using a Rapid Visco Analyzer (RVA 4500, Pty Ltd., Warriewood, Australia). A 3.0 g of sample (14\%, w. b.) were dispersed in $25 \mathrm{~mL}$ of distilled water into the RVA canister, stirred manually by rotating the plastic paddle. The suspension was subjected to heating-cooling cycle with a constant shear rate $(160 \mathrm{rpm})$, it was held at $50{ }^{\circ} \mathrm{C}$ for $1 \mathrm{~min}$, heated to $95^{\circ} \mathrm{C}$ at $6^{\circ} \mathrm{C} / \mathrm{min}$, and held at $95^{\circ} \mathrm{C}$ for $5 \mathrm{~min}$, and then it was cooled and held to $50^{\circ} \mathrm{C}$. The following parameters were estimated: pasting temperature; peak viscosity (PV); trough viscosity (TV); breakdown $(\mathrm{BD})=(\mathrm{PV}-\mathrm{TV})$; final viscosity $(\mathrm{FV})$ and setback viscosity $(\mathrm{SB})=(\mathrm{FV}-\mathrm{TV})$.

\subsection{Syneresis Property}

Retrogradation of flour starch measured by syneresis was carried out according to the method described by Kuar et al. [20] with minor modifications. Flour suspension ( $6 \%$ flour in water, w/w) was heated at $85{ }^{\circ} \mathrm{C}$ for $30 \mathrm{~min}$ in a temperature controlled water bath, and then cooled to room temperature in an ice water bath for 5 min. The cooled samples were stored for 1, 2, 3 and 6 days at $4^{\circ} \mathrm{C}$. The ratio of the weight of liquid separated from the sample to the total weight of the sample before centrifugation (at $4500 \mathrm{rpm}$ for $15 \mathrm{~min}$ ), and multiplied by 100 was calculated as the percentage of syneresis of stored sample.

\subsection{Statistical Analysis}

All procedures were done in triplicates and collected data subjected to analysis of variance (ANOVA). The differences among means were separated using Duncan's multiple range test and significances were accepted at 5\% level $(p<0.05)$. The statistical software used was SPSS version 16.0 for windows (SPSS Inc., Chicago, USA).

\section{Results and Discussion}

\subsection{Chemical Composition}

The chemical composition of the sweet potato flour (SPF), glutinous rice flour (GRF), button mushroom (Agaricus bisporus) powder (BMP) and the blends is shown in Table 1. BMP had high protein content (27.91 $\mathrm{g} / 100 \mathrm{~g})$, total dietary fiber $(17.44 \mathrm{~g} / 100 \mathrm{~g})$, ash content (7.27 g/100 g), and fat content (2.22 g/100 g), but lower contents of moisture $(8.47 \mathrm{~g} / 100 \mathrm{~g})$ and carbohydrate (54.11 g/100 g), while SPF and GRF were observed to have lower contents of protein $(3.33 \mathrm{~g} / 100 \mathrm{~g}$ and 8.04 $\mathrm{g} / 100 \mathrm{~g})$, ash (0.97 g/100 g and $1.03 \mathrm{~g} / 100 \mathrm{~g})$ and fat (0.33 g/100 g and $1.03 \mathrm{~g} / 100 \mathrm{~g})$; and higher moisture (12.10 g/100 g and $13.37 \mathrm{~g} / 100 \mathrm{~g})$ and carbohydrate (83.47 g/100 g and $76.51 \mathrm{~g} / 100 \mathrm{~g})$, respectively. The high protein, total dietary fibers and ash, and low moisture content in BMP used in the fortification of the SPF-GRF affected in the increase of protein, fiber and ash contents, and the decrease in moisture of the composite gluten-free flour, especially BMP $\mathrm{T}_{3}$ as compared to inulin treatments and control (Table 1). Uju and Obiakar-Okeke [21] found lower moisture (5.24 g/100 g), ash (3.27 g/100 g), protein $(11.91 \mathrm{~g} / 100 \mathrm{~g})$ and higher fat $(6.90 \mathrm{~g} / 100 \mathrm{~g})$ contents in BMP from Nigeria, whereas, Ojo et al. [22] also stated slightly lower protein (26.23 g/100 g) for Oyster mushroom (Pleurotus pulmonaris) compared to the present study. High dietary fiber blends are considered efficient protective constituents against several varieties of disorders, such as cardiovascular disease, colon cancer and constipation. The ash content in BMP in the present investigation was in line with ash content (7.48 g/100 g) in oyster mushroom dried in laboratory oven, which reported by Aishah and Wan Rosli [23], and lower than that found by Jeong et al. [24] in BMP (8.70 g/100 g. The low moisture content of the blends lead to long shelf life during storage, while high content of moisture cause a microbial growth, especially higher than $12 \%$. The energy value of inulin $\mathrm{T}_{3}$ was higher (355.93 kcal/100 g) than BMP $\mathrm{T}_{3}$ (350.77 kcal/100 g), whereas for control flour was the lowest (346.69 kcal/100 g). It was observed that moisture and carbohydrate contents were decreased with increasing level of BMP in composite gluten-free flour, whereas energy values were increased with increasing 
both BMP and inulin (Table 1). This is possibly due to increment in total dietary fiber and protein contents, and decrement in starch level.

\subsection{Amino Acid Composition}

Amino acids are necessary for the synthesis of most body tissues, enzymes and hormones, in addition to the nutritional quality of protein depends primarily on the composition of amino acids. In food processing, amino acids and protein contribute to the flavor, aroma and texture. The results of amino acids of SPF, GRF, BMP and the blends are listed in Table 2. Total of 9 essential amino acids and 8 non-essential amino acids were detected in all the samples. The total essential amino acids composition of the composite gluten-free flour was increment from $326.42 \mathrm{mg} / 100 \mathrm{~g}$ for control to 2022.89 and $413.00 \mathrm{mg} / 100 \mathrm{~g}$ for $\mathrm{BMP} \mathrm{T}_{3}$ and inulin $\mathrm{T}_{3}$, respectively. BMP $\mathrm{T}_{3}$ had the highest total amino acids (5599.26 mg/100 g) among all the samples, due to it contained high protein content in comparison to the other blends, especially inulin treatments. BMP revealed the highest amino acids content followed by GRF and then SPF. Glutamic and aspartic acids were the most abundant non-essential amino acids in all the samples, while cysteine content showed the lowest one. All the samples had the highest essential amino acids of valine, isoleucine, leucine and lysine values, while they had lowest histidine level (Table 2). Ekunseitan et al. [25] reported that aspartic acid, lysine and tryptophan increased with inclusion of mushroom powder in the flour blends. Generally, Agaricus bisporus possesses high content of amino acids according to its protein content among the other edible mushroom varieties.

Table 1. Proximate composition (g/100 g) of flours, button mushroom powder and composite gluten-free flour fortified with button mushroom powder and inulin

\begin{tabular}{|c|c|c|c|c|c|c|c|c|c|c|}
\hline \multirow[t]{2}{*}{ Parameter } & \multirow[b]{2}{*}{ SPF } & \multirow[b]{2}{*}{ GRF } & \multirow[b]{2}{*}{ BMP } & \multirow[b]{2}{*}{ Control } & \multicolumn{3}{|c|}{ BMP } & \multicolumn{3}{|c|}{ Inulin } \\
\hline & & & & & $\mathrm{T}_{1}$ & $\mathbf{T}_{2}$ & $\mathbf{T}_{3}$ & $\mathbf{T}_{1}$ & $\mathbf{T}_{2}$ & $\mathbf{T}_{3}$ \\
\hline Moisture & $12.10 \pm 0.10^{\mathrm{d}}$ & $13.37 \pm 0.02^{\mathrm{a}}$ & $8.47 \pm 0.01^{\mathrm{i}}$ & $12.53 \pm 0.03^{\mathrm{c}}$ & $11.93 \pm 0.02^{\mathrm{e}}$ & $11.43 \pm 0.04^{g}$ & $11.13 \pm 0.02^{\mathrm{h}}$ & $12.83 \pm 0.11^{\mathrm{b}}$ & $11.66 \pm 0.09^{f}$ & $11.07 \pm 0.07^{\mathrm{h}}$ \\
\hline Ash & $1.17 \pm 0.01^{\mathrm{f}}$ & $1.06 \pm 0.03^{\mathrm{g}}$ & $7.29 \pm 0.02^{\mathrm{a}}$ & $1.23 \pm 0.03^{\mathrm{e}}$ & $1.66 \pm 0.02^{\mathrm{d}}$ & $2.03 \pm 0.01^{c}$ & $2.34 \pm 0.02^{\mathrm{b}}$ & $0.14 \pm 0.01^{\mathrm{h}}$ & $0.13 \pm 0.00^{\mathrm{h}}$ & $0.11 \pm 0.02^{\mathrm{h}}$ \\
\hline $\begin{array}{l}\text { Protein } \\
\left(\mathrm{N}^{*} 6.25\right)\end{array}$ & $2^{\mathrm{h}}$ & $2^{e}$ & & 5.24 & & & & & $07^{\mathrm{f}}$ & \\
\hline Fat & $0.33 \pm 0.01^{\mathrm{f}}$ & $1.03 \pm 0.01^{\mathrm{b}}$ & $2.22 \pm 0.01^{\mathrm{a}}$ & $0.15 \pm 0.00^{\mathrm{h}}$ & $0.40 \pm 0.02^{\mathrm{e}}$ & $0.66 \pm 0.01^{\mathrm{d}}$ & $0.93 \pm 0.02^{c}$ & $0.14 \pm 0.01^{\mathrm{g}}$ & $0.17 \pm 0.03^{\mathrm{g}}$ & $0.13 \pm 0.02^{\mathrm{g}}$ \\
\hline $\begin{array}{c}\text { Tot. } \\
\text { arbohydrate }\end{array}$ & $e^{83 .}$ & . & 54 & 80.8 & 7 & 76.0 & $\begin{array}{c}73.86 \pm \\
0.014^{i}\end{array}$ & $81.67 \pm 0.10^{\mathrm{d}}$ & 82.8 & 83. \\
\hline $\begin{array}{c}\text { Energy } \\
\text { (kcal/100g) }\end{array}$ & $\begin{array}{c}348.57 \pm \\
0.23^{\mathrm{f}}\end{array}$ & $\begin{array}{c}347.43 \pm \\
0.07^{\mathrm{i}}\end{array}$ & $\begin{array}{c}348.06 \pm \\
0.08^{\mathrm{g}}\end{array}$ & $345.71 \pm 0.2^{\mathrm{j}}$ & $\begin{array}{c}347.64 \pm \\
0.13^{\mathrm{h}}\end{array}$ & $\begin{array}{c}349.46 \pm \\
0.12^{\mathrm{d}}\end{array}$ & $\begin{array}{c}350.77 \pm \\
0.28^{\mathrm{c}}\end{array}$ & $\begin{array}{c}348.82 \pm \\
0.22^{\mathrm{e}}\end{array}$ & $\begin{array}{c}353.69 \pm \\
0.17^{\mathrm{b}}\end{array}$ & $\begin{array}{c}355.93 \pm \\
0.20^{\mathrm{a}}\end{array}$ \\
\hline IDF & $3.01 \pm 0.03^{\mathrm{e}}$ & ND & $13.70 \pm 0.07^{\mathrm{a}}$ & $2.75 \pm 0.01^{\mathrm{f}}$ & $3.72 \pm 0.05^{\mathrm{d}}$ & $4.70 \pm 0.04^{\mathrm{c}}$ & $5.13 \pm 0.03^{b}$ & $2.71 \pm 0.03^{f}$ & $2.67 \pm 0.06^{\mathrm{fg}}$ & $2.59 \pm 0.07^{\mathrm{g}}$ \\
\hline SDF & $1.09 \pm 0.02^{\mathrm{h}}$ & ND & $3.74 \pm 0.05^{\mathrm{a}}$ & $1.22 \pm 0.01^{\mathrm{g}}$ & $1.94 \pm 0.05^{\mathrm{d}}$ & $2.80 \pm 0.03^{c}$ & $3.48 \pm 0.03^{b}$ & $1.68 \pm 0.01^{\mathrm{f}}$ & $1.71 \pm 0.01^{\mathrm{f}}$ & $1.77 \pm 0.03^{\mathrm{e}}$ \\
\hline TDF & $4.10 \pm 0.05^{\mathrm{f}}$ & ND & $17.44 \pm 0.12^{\mathrm{a}}$ & $3.97 \pm 0.03^{g}$ & $5.66 \pm 0.10^{d}$ & $7.50 \pm 0.08^{\mathrm{c}}$ & $8.61 \pm 0.06^{\mathrm{b}}$ & $4.39 \pm 0.08^{\mathrm{e}}$ & $4.38 \pm 0.10^{\mathrm{e}}$ & $4.36 \pm 0.05^{\mathrm{e}}$ \\
\hline
\end{tabular}

Mean \pm standard deviation $(n=3)$. Mean values within a raw followed by a different letters are significantly different $(p<0.05)$. SPF $=$ sweet potato flour; GRF = glutinous rice flour; BMP = button mushroom powder; IDF = insoluble dietary fiber, SDF = soluble dietary fiber, TDF = total dietary fiber, $\mathrm{ND}=$ not detected.

Table 2. Amino acids composition (mg/100 g) of flours, button mushroom powder and composite gluten-free flour fortified with button mushroom powder and inulin

\begin{tabular}{|c|c|c|c|c|c|c|c|c|c|c|}
\hline \multirow[t]{2}{*}{ Amino acid } & \multirow[b]{2}{*}{ SPF } & \multirow[b]{2}{*}{ GRF } & \multirow[b]{2}{*}{ BMP } & \multirow[b]{2}{*}{ Control } & \multicolumn{3}{|c|}{ BMP } & \multicolumn{3}{|c|}{ Inulin } \\
\hline & & & & & $\mathbf{T}_{1}$ & $\mathbf{T}_{2}$ & $\mathbf{T}_{3}$ & $\mathbf{T}_{1}$ & $\mathbf{T}_{2}$ & $\mathbf{T}_{3}$ \\
\hline Aspartic acid & 93.14 & 520.42 & 2136.8 & 106.39 & 381.61 & 535.72 & 677.49 & 105.56 & 100.21 & 112.09 \\
\hline Glutamic acid & 26.9 & 1181.6 & 4900.38 & 130.82 & 711.42 & 1032.44 & 1349.82 & 149.67 & 207.91 & 147.29 \\
\hline Tyrosine & 4.13 & 98.42 & 391.23 & 17.09 & 49.76 & 83.97 & 119.74 & 39.31 & 30.57 & 55.17 \\
\hline Serine & 2.62 & 88.14 & 3595.1 & 10.95 & 56.01 & 78.58 & 102.21 & 36.94 & 40.44 & 43.21 \\
\hline Proline & 20.53 & 248.43 & 1250.51 & 50.52 & 166.33 & 219.57 & 292.81 & 73.38 & 85.68 & 84.87 \\
\hline Alanine & 8.23 & 301.33 & 1520.12 & 46.8 & 202.17 & 295.04 & 382.78 & 58.99 & 64.64 & 84.83 \\
\hline Cysteine & 1.67 & 10.62 & 23.32 & 1.65 & 2.34 & 4.13 & 6.19 & 6.04 & 1.49 & 0.68 \\
\hline Arginine* & 9.52 & 335.58 & 1305.45 & 56.11 & 180.51 & 276.63 & 370.66 & 63.16 & 59.66 & 81.35 \\
\hline Histidine* & 0.63 & 107.09 & 215.72 & 13.15 & 64.22 & 90.75 & 115.96 & 21.67 & 21.62 & 24.36 \\
\hline Threonine* & 3.76 & 183.77 & 600.78 & 26.04 & 136.64 & 197.77 & 254.74 & 25.24 & 27.69 & 31.44 \\
\hline Valine* & 23.95 & 365.06 & 1242.09 & 56.8 & 212.02 & 297.84 & 374.71 & 64.43 & 68.95 & 74.85 \\
\hline Methionine* & 20.12 & 122.25 & 294.14 & 23.85 & 64.37 & 88.66 & 110.33 & 8.87 & 8.92 & 10.99 \\
\hline Isoleucine* & 15.63 & 273 & 1003.37 & 41.83 & 165.07 & 231.32 & 299.27 & 29.37 & 35.77 & 33.02 \\
\hline Leucine* & 26.78 & 478.69 & 1566.58 & 76.12 & 258.43 & 360.5 & 261.38 & 75.19 & 77.04 & 71.19 \\
\hline Lysine* & 20.03 & 126.2 & 878.64 & 31.48 & 143.23 & 201.06 & 295.79 & 33.66 & 27.55 & 29.97 \\
\hline TNAA & 171.39 & 3000.32 & 16190.85 & 445.82 & 1886.4 & 2726.01 & 3576.37 & 507.03 & 571.09 & 572.02 \\
\hline TEAA & 125.58 & 1983.66 & 6756.39 & 326.42 & 1218.28 & 1714.64 & 2022.89 & 340.59 & 378.22 & 413.00 \\
\hline TAA & 296.97 & 4983.98 & 22947.24 & 772.24 & 3104.68 & 4440.65 & 5599.26 & 847.62 & 949.31 & 985.02 \\
\hline
\end{tabular}

The values represent the average of two determinations. SPF = sweet potato flour; GRF = glutinous rice flour; BMP $=$ button mushroom powder.

*Essential amino acids; TEAA = total essential amino acids; TNAA = total non-essential amino acids, TAA = total amino acids. 


\subsection{Minerals Composition}

The major and trace minerals are essential for several physiological functions in the human body. Supplementation of SPF-GRF with BMP resulted in increase of minerals content of calcium (Ca), phosphorus $(\mathrm{P})$, potassium $(\mathrm{K})$, magnesium $(\mathrm{Mg})$, sodium $(\mathrm{Na})$, iron $(\mathrm{Fe})$, zinc $(\mathrm{Zn})$ and copper $(\mathrm{Cu})$, and the values are presented in Table 3. SPF had higher Ca content (88.35 $\mathrm{mg} / 100 \mathrm{~g}$ ) than GRF (28.79 mg/100 g), while BMP was the highest in all minerals content. $\mathrm{BMP} \mathrm{T}_{3}$ of composite flour showed the highest K (456.61 mg/100 g), Ca (282.81 $\mathrm{mg} / 100 \mathrm{~g}), \mathrm{P}$ (225.26 mg/100 g), and Fe (6.93 mg/100 g) values, whereas BMP $\mathrm{T}_{1}$ and control demonstrated the lowest contents of these minerals (Table 3). Higher calcium intake by celiac disease patients is important because of after prolonged ingestion of gluten-free diet, absorption of calcium remain impaired [26]. From this point of view, addition of BMP to SPF, besides skim milk powder in the formulation is interesting for development of gluten-free products, which may contain high calcium content. The presence of calcium in the blend is an essential component for human's health and is required for formation and strengthens of bones and teeth, in addition to responsible for blood clot. With respect to magnesium (Mg), low intake of $\mathrm{Mg}$ in children on gluten-free products was reported by Ohlund et al. [27], therefore enrichment of SPF with BMP would have positive impact on $\mathrm{Mg}$ content. Overall, the higher ash content in the blends, the higher minerals content.

\subsection{Functional Properties}

Functional characteristics of food materials are important factors to consider in food industry or in the formulation of new food products. The findings of functional properties of SPF, GRF, BMP and the composite gluten-free flour are reported in Figure 1a, b, c and $d$. The bulk density of present study for SPF was $0.61 \mathrm{~g} / \mathrm{mL}$ followed by GRF $(0.55 \mathrm{~g} / \mathrm{mL})$ and then BMP $(0.42 \mathrm{~g} / \mathrm{mL})$. It was noted that there was no significant difference $(p>0.05)$ in bulk density values between SPF and GRF (Figure 1a). The water absorption index (WAI) and oil absorption index (OAI) of the BMP were found to be the highest $(4.54 \mathrm{~g} / \mathrm{g}$ and $3.63 \mathrm{~g} / \mathrm{g}$ ) compared to SPF (1.72 g/g and $1.98 \mathrm{~g} / \mathrm{g})$ and GRF (2.11 g/g and $2.46 \mathrm{~g} / \mathrm{g}$ ), respectively (Figure 1a). While SPF had the highest swelling power (15.79 $\mathrm{g} / \mathrm{g})$ and the lowest solubility (28.34\%) and BMP had the lowest swelling power (10.51 g/g) and the highest solubility (35.13\%) (Figure 1b). The higher WAI, OAI and solubility of BMP might be due to high in its protein, total dietary fiber and pigments levels as compared to SPF and GRF. According to [28], high availability of polar amino acids in sample protein possessed strong affinity for water molecules. Similar swelling power $(15.80 \mathrm{~g} / \mathrm{g})$ and different solubility (27.00\%) values in SPF has been reported by Yadav et al. [29]. Swelling power and solubility are influenced by amylose and amylopectin characteristics, interaction between the water molecules and the flour starch chains in the amorphous and crystalline areas, and the present of phosphorus and starch granules [30,31]. There were no significant differences $(p>0.05)$ in bulk density among control, BMP $\mathrm{T}_{1}, \mathrm{~T}_{2}$ and inulin $\mathrm{T}_{2}$. In addition, water and oil absorption indexes of composite gluten-free flour significantly increased with increasing level of mushroom powder and slight decreased with increasing inulin content (Figure 1c), as well as BMP $\mathrm{T}_{1}$ exhibited the highest solubility (24.1\%), while inulin $\mathrm{T}_{1}$ revealed the highest swelling power (31.73 g/g) and lowest solubility (2.6\%) among all the samples (Figure 1d). Moreover, swelling power decreased and solubility increased with increasing BMP and inulin in the blends, it would be explained by the fact that incorporation of mushroom powder and inulin mainly consisted of water insoluble dietary fiber and water soluble dietary fiber, respectively. Additionally, this is related to increased levels of protein and minerals from BMP fortification and decreased content of starch in composite flour. Addition of mushroom flour to the cassava starch with different levels led to decrement in solubility, which could be as a result of increment in non-starch polysaccharides, namely insoluble dietary fibers (chitin and $\beta$-glucan), in addition to less increase in soluble dietary fibers [22]. Kim et al. [32] interpreted that the swelling and breakdown of starch granules by gelatinization allow them easily join with water molecular. Moreover, amylopectin content contributes to swelling of starch granules and improves pasting characteristics, whereas amylose and lipids contents inhibit swelling [33]. In general, higher increase in nutrients such as protein, lipids, fibers and minerals for composite gluten-free flour led to decrement in swelling power and increment in solubility, water and oil absorption properties.

Table 3. Minerals composition (mg/100 g) of flours, button mushroom powder and composite gluten-free flour fortified with button mushroom powder

\begin{tabular}{cccccccc}
\hline Minerals & SPF & GRF & BMP & Control & BMP T $_{\mathbf{1}}$ & BMP T $_{2}$ \\
\hline Ca & $88.35 \pm 0.21^{\mathrm{e}}$ & $28.79 \pm 0.01^{\mathrm{g}}$ & $450.22 \pm 0.04^{\mathrm{a}}$ & $44.09 \pm 0.02^{\mathrm{f}}$ & $271.81 \pm 0.03^{\mathrm{d}}$ & $280.79 \pm 0.03^{\mathrm{c}}$ & $282.81 \pm 0.03^{\mathrm{b}}$ \\
$\mathbf{M g}$ & $29.66 \pm 0.01^{\mathrm{e}}$ & $20.49 \pm 0.03^{\mathrm{f}}$ & $351.56 \pm 0.01^{\mathrm{a}}$ & $12.84 \pm 0.01^{\mathrm{g}}$ & $151.94 \pm 0.02^{\mathrm{d}}$ & $172.67 \pm 0.02^{\mathrm{c}}$ & $191.14 \pm 0.02^{\mathrm{b}}$ \\
$\mathbf{K}$ & $39.40 \pm 0.14^{\mathrm{f}}$ & $22.71 \pm 0.42^{\mathrm{h}}$ & $2780.16 \pm 0.23^{\mathrm{a}}$ & $23.93 \pm 0.01^{\mathrm{g}}$ & $221.71 \pm 0.56^{\mathrm{d}}$ & $342.68 \pm 0.66^{\mathrm{c}}$ & $456.61 \pm 0.71^{\mathrm{b}}$ \\
$\mathbf{P}$ & $55.61 \pm 0.69^{\mathrm{g}}$ & $25.47 \pm 0.46^{\mathrm{h}}$ & $356.50 \pm 0.71^{\mathrm{a}}$ & $57.07 \pm 0.06^{\mathrm{f}}$ & $111.17 \pm 0.25^{\mathrm{d}}$ & $158.21 \pm 0.30^{\mathrm{c}}$ & $225.26 \pm 0.37^{\mathrm{b}}$ \\
$\mathbf{N a}$ & $26.71 \pm 0.01^{\mathrm{h}}$ & $38.16 \pm 0.08^{\mathrm{e}}$ & $473.24 \pm 0.04^{\mathrm{a}}$ & $31.94 \pm 0.02^{\mathrm{g}}$ & $41.59 \pm 0.30^{\mathrm{d}}$ & $77.86 \pm 0.07^{\mathrm{c}}$ & $80.64 \pm 0.15^{\mathrm{b}}$ \\
$\mathbf{C u}$ & $1.32 \pm 0.02^{\mathrm{g}}$ & $1.38 \pm 0.01^{\mathrm{f}}$ & $4.30 \pm 0.05^{\mathrm{a}}$ & $1.19 \pm 0.01^{\mathrm{h}}$ & $3.30 \pm 0.03^{\mathrm{d}}$ & $3.37 \pm 0.03^{\mathrm{c}}$ & $3.45 \pm 0.07^{\mathrm{b}}$ \\
$\mathbf{Z n}$ & $0.84 \pm 0.03^{\mathrm{f}}$ & $1.73 \pm 0.03^{\mathrm{d}}$ & $10.39 \pm 0.05^{\mathrm{a}}$ & $0.76 \pm 0.01^{\mathrm{g}}$ & $1.18 \pm 0.02^{\mathrm{e}}$ & $2.26 \pm 0.01^{\mathrm{c}}$ & $2.33 \pm 0.06^{\mathrm{b}}$ \\
Fe & $0.94 \pm 0.01^{\mathrm{h}}$ & $1.21 \pm 0.13^{\mathrm{g}}$ & $30.99 \pm 0.16^{\mathrm{a}}$ & $2.36 \pm 0.02^{\mathrm{f}}$ & $3.76 \pm 0.06^{\mathrm{d}}$ & $5.73 \pm 0.02^{\mathrm{c}}$ & $6.93 \pm 0.08^{\mathrm{b}}$ \\
\hline
\end{tabular}

Mean \pm standard deviation $(n=3)$. Mean values within a raw followed by a different letters are significantly different $(p<0.05)$. SPF $=$ sweet potato flour; GRF = glutinous rice flour; BMP = button mushroom powder. 

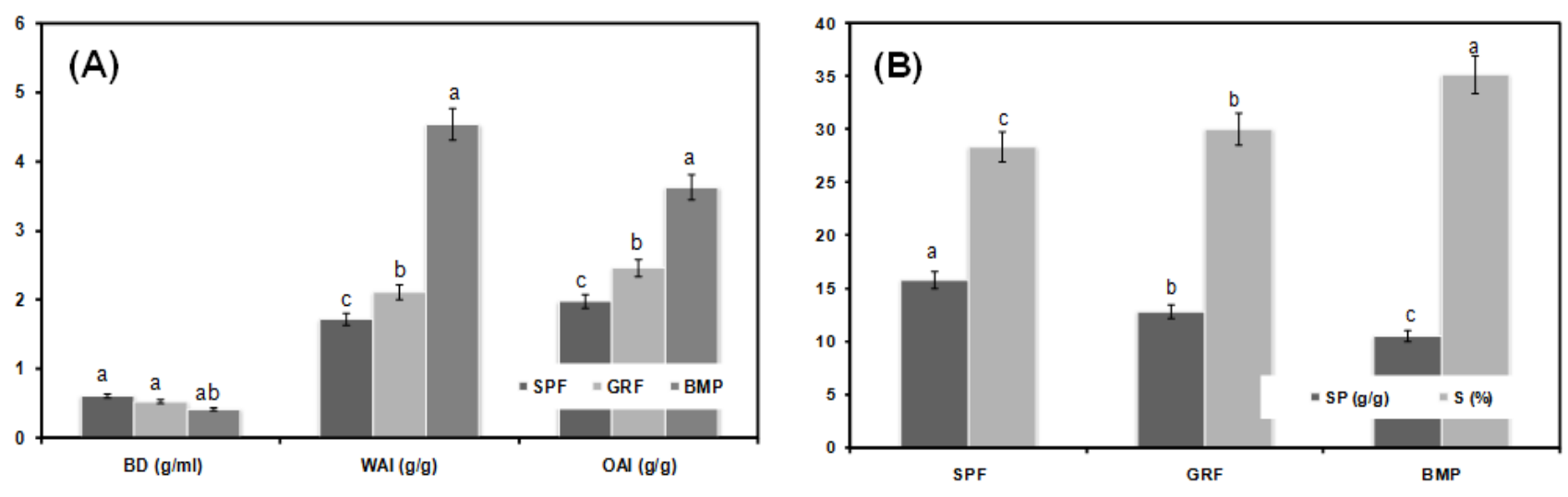

Bulk density, water absorption index and oil absorption index

Sweet potato flour, glutinous rice flour and button mushroom powder
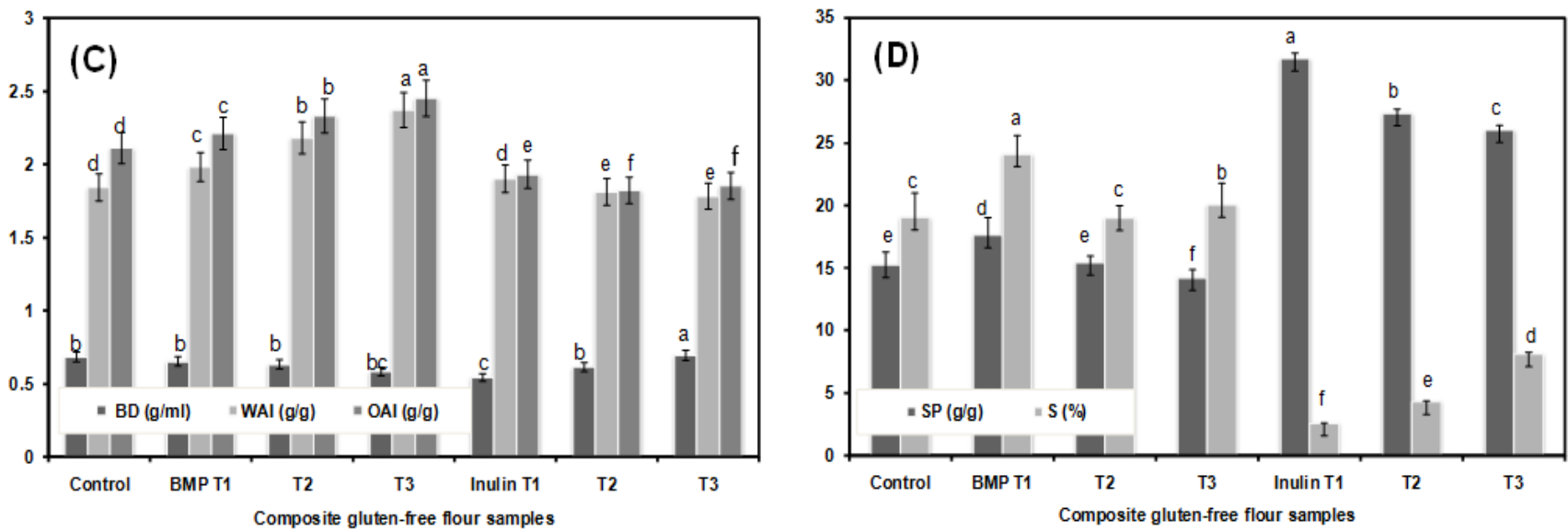

Figure 1. Functional properties of sweet potato flour (SPF), glutinous rice flour (GRF) button mushroom powder (BMP) and composite gluten-free flour fortified with BMP and inulin (A and B = flours; C and D = composite gluten-free flours). Error bars indicate standard deviations. Mean values, marked with different letters are significantly different

\subsection{Pasting Properties}

Viscosity properties of flours and composite gluten-free flour are displayed in Table 4. There were significant differences $(p<0.05)$ in viscosity parameters (peak viscosity, breakdown viscosity...) among all the samples. The PV of SPF and GRF were 4270.50 and 2263.10 cP, respectively while the $\mathrm{PV}$ of composite flour in the range of $3428.04 \mathrm{cP}$ for BMP $\mathrm{T}_{1}$ to $2568.08 \mathrm{cP}$ for $\mathrm{BMP} \mathrm{T}_{3}$, and $2730.13 \mathrm{cP}$ for inulin $\mathrm{T}_{3}$, which were lower than control (3629.21cP). In this present study, SPF had higher viscosity compared to GRF. GRF and $T_{3}$ of BMP had the lowest trough viscosity (TV), breakdown viscosity (BD), setback viscosity (SB) and final viscosity (FV), and the values obtained were 1101.40, 1163.65, 1645.29 and 546.13 сp for GRF and 1108.59, 1460.75, 1649.81 and 541.73 cP for BMP $\mathrm{T}_{3}$, respectively. These results revealed that addition of high levels of BMP and inulin reduced all the viscosity parameters of composite glutenfree flour, while pasting temperature (PT) of composite gluten-free flour slightly increased with increasing level of BMP and inulin in the blends as compared to control sample. This is due to decreased in starch content and increased in dietary fibres, protein and fat contents in composite gluten-free flour. However, no significant differences were observed among the control, $\mathrm{T}_{1}$ and $\mathrm{T}_{2}$ of BMP and inulin treatments in TV (Table 4). Batey and Curtin [34] reported that the starch and protein contents in the flours and the blends could affect viscosity properties.
The decreased in BD and FV with increasing BMP and inulin in the blends may be result from swelling of flour starch granules, which increased the tendency of soluble and insoluble dietary fibers in composite flour to bind with hydrogen bonds of the water, causing shortage in available water for flour starch granules. The lower the $\mathrm{BD}$, the higher the ability of the blends to form viscous paste or gel after cooking and cooling, as well as low value of $\mathrm{BD}$ resulted in high stability of paste to shear stress during stirring [35]. BMP $\mathrm{T}_{3}$ had the lowest $\mathrm{SB}$ viscosity value, indicating the more retrogradation during cooling and high staling rate for its baked product.

\subsection{Syneresis \%}

The degree of flour starch retrogradation at low temperature during storage period is measured using syneresis property. The syneresis of flours and composite gluten-free flour stored for 6 days at $4{ }^{\circ} \mathrm{C}$ is shown in Figure $2 \mathrm{a}$ and Figure $2 \mathrm{~b}$. SPF exhibited higher retrogradation tendency due to the large amount of water separated during retrograding process compared to GRF. Moreover, SPF had the highest syneresis in the 2nd and 3rd day of storage, whereas GRF revealed the highest syneresis in the 3rd and 4th day of storage (Figure 2a). Percentage syneresis of composite gluten-free flour increased with increasing level of BMP and decrement with increment inulin content, and increased with increase in the first 3 storage days, and then decreased in the last 3 days of storage (Figure 2b). In addition, control sample 
revealed the lowest syneresis $(p<0.05)$ compared to BMP and inulin treatments. The higher tendency of retrogradation observed in SPF starch might be result of its higher amylose content, while lowest syneresis in GRF starch due to its lower amylose content (0-2\%). Charoenrein and Preechathammawong [36] mentioned that starch gel containing GRF had lower syneresis through freeze-thaw cycles, as well as amylose content played a significant role in the retrogradation associated with freezing and thawing. GRF paste had higher viscosity, lower retrogradation rate and softer gel than that of nonglutinous rice [37]. Among the composite gluten-free flour treatments, $T_{1}$ and $T_{2}$ of BMP and inulin $T_{3}$ had significantly $(p<0.05)$ lower syneresis as compared to the other treatments. This could be explained by mean that decrement in starch content and increment in protein and total dietary fibers levels in the composite gluten-free flour. There is a significant positive correlation between syneresis property and amylose content. Ribotta et al. [38] pointed out that the protein-retained water could be easily separated compared to the starch-retained water during cold storage period. The presence of hydrocolloids or sugars in starch gel could bind with water molecules and reduced the syneresis [39]. Addition of gums, such as xanthan gum and guar gum to the blends or formulation was minimized retrogradation of amylose and syneresis after freezing due to an interaction between the starch molecules and the hydrocolloids [36].

Table 4. Pasting properties (viscosity, $\mathrm{cP}$ ) of flours and composite gluten-free flour fortified with button mushroom powder and inulin

\begin{tabular}{|c|c|c|c|c|c|c|}
\hline Sample & Peak V & Trough & Breakdown & Final V & Set back & Pasting $T_{m}\left({ }^{\circ} \mathbf{C}\right)$ \\
\hline SPF & $4270.50 \pm 1.71^{\mathrm{a}}$ & $1534.34 \pm 1.66^{\mathrm{a}}$ & $2732.31 \pm 0.22^{\mathrm{a}}$ & $2489.00 \pm 1.69^{\mathrm{a}}$ & $951.05 \pm 0.15^{\mathrm{a}}$ & $69.15 \pm 0.01^{c}$ \\
\hline GRF & $2263.10 \pm 0.99^{f}$ & $1101.40 \pm 0.71^{\mathrm{c}}$ & $1163.65 \pm 0.14^{f}$ & $1645.29 \pm 1.47^{\mathrm{c}}$ & $546.13 \pm 0.19^{\mathrm{bc}}$ & $69.10 \pm 0.00^{c}$ \\
\hline Control & $3629.21 \pm 1.09^{b}$ & $1330.11 \pm 0.83^{b}$ & $2300.08 \pm 1.25^{b}$ & $2300.33 \pm 0.97^{\mathrm{a}}$ & $971.67 \pm 0.17^{\mathrm{a}}$ & $69.90 \pm 0.02^{c}$ \\
\hline $\mathrm{BMP}_{\mathrm{T}}$ & $3428.04 \pm 0.91^{\mathrm{c}}$ & $1342.39 \pm 1.72^{\mathrm{b}}$ & $2082.00 \pm 1.59^{\mathrm{C}}$ & $2094.41 \pm 1.39^{\mathrm{b}}$ & $752.49 \pm 0.22^{b}$ & $69.50 \pm 0.02^{c}$ \\
\hline $\mathbf{T}_{2}$ & $3103.11 \pm 0.96^{\mathrm{d}}$ & $1327.22 \pm 0.89^{\mathrm{b}}$ & $1777.51 \pm 0.91^{d}$ & $2004.94 \pm 1.21^{\mathrm{b}}$ & $677.61 \pm 0.19^{b}$ & $70.90 \pm 0.01^{\mathrm{b}}$ \\
\hline $\mathbf{T}_{3}$ & $2568.08 \pm 1.41^{\mathrm{ed}}$ & $1108.59 \pm 0.92^{c}$ & $1460.75 \pm 1.33^{\mathrm{e}}$ & $1649.81 \pm 1.34^{\mathrm{c}}$ & $541.73 \pm 0.22^{\mathrm{bc}}$ & $71.90 \pm 0.01^{\mathrm{a}}$ \\
\hline Inulin $\mathbf{T}_{1}$ & $2664.22 \pm 1.01^{\mathrm{e}}$ & $1233.07 \pm 0.98^{\mathrm{b}}$ & $1433.59 \pm 1.00^{\mathrm{e}}$ & $1857.36 \pm 0.67^{\mathrm{bc}}$ & $624.19 \pm 0.12^{\mathrm{b}}$ & $71.95 \pm 0.03^{\mathrm{a}}$ \\
\hline $\mathbf{T}_{2}$ & $2367.00 \pm 1.10^{\mathrm{d}}$ & $1236.21 \pm 0.69^{b}$ & $1131.34 \pm 0.88^{f}$ & $1919.50 \pm 1.31^{b}$ & $683.06 \pm 0.35^{\mathrm{b}}$ & $71.90 \pm 0.00^{\mathrm{a}}$ \\
\hline $\mathbf{T}_{3}$ & $2730.13 \pm 1.19^{\mathrm{e}}$ & $1252.74 \pm 0.95^{\mathrm{b}}$ & $1478.48 \pm 1.05^{\mathrm{e}}$ & $1862.79 \pm 1.53^{\mathrm{bc}}$ & $610.21 \pm 0.31^{\mathrm{b}}$ & $71.95 \pm 0.01^{\mathrm{a}}$ \\
\hline
\end{tabular}

Mean \pm standard deviation $(\mathrm{n}=3)$. Mean values within a column followed by a different letters are significantly different $(p<0.05)$. SPF $=$ sweet potato flour; GRF = glutinous rice flour; BMP = button mushroom powder.

(A)

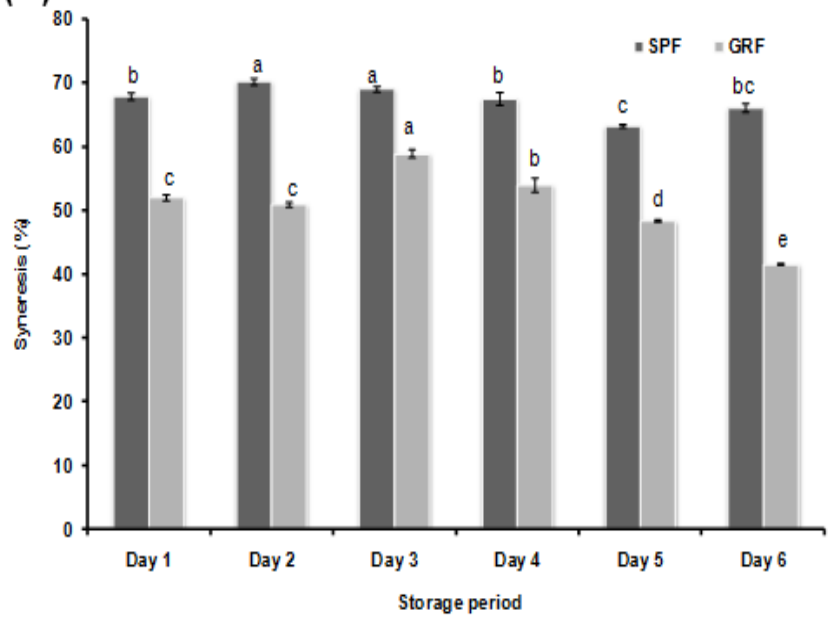

(B)

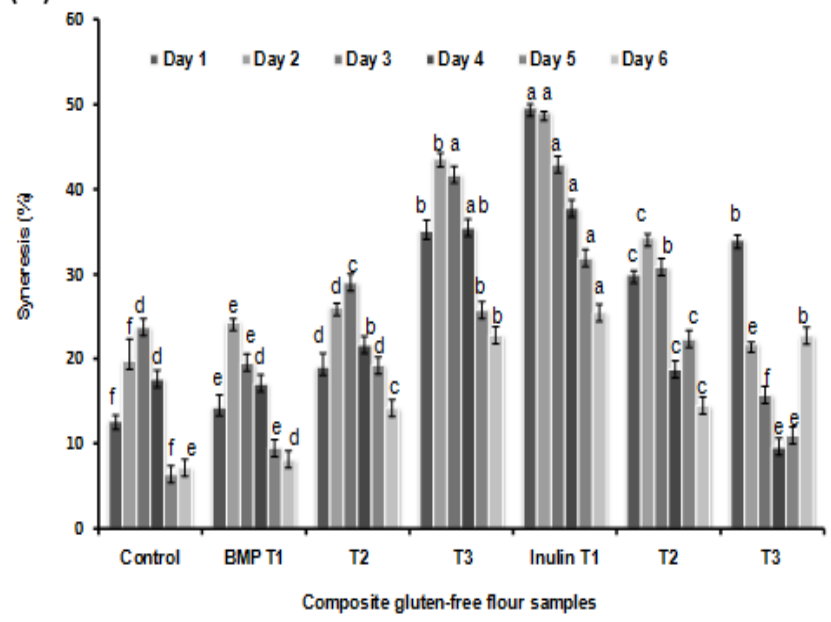

Figure 2. Syneresis percentage of sweet potato flour (SPF), glutinous rice flour (GRF) and composite gluten-free flour fortified with BMP and inulin, stored at $4{ }^{\circ} \mathrm{C}$ for 6 days ( $\mathrm{A}=\mathrm{SPF}$ and GRF; $\mathrm{B}=$ control and $\mathrm{T}_{1}, \mathrm{~T}_{2}, \mathrm{~T}_{3}$ of both BMP and inulin). Error bars indicate standard deviations. Mean values, marked with different letters are significantly different

\section{Conclusions}

Fortification of SPF-GRF with BMP and inulin improved its chemical composition in terms of protein, amino acids, minerals, and dietary fibers with reduced carbohydrate in case of BMP addition, and subsequently they appropriate for nutritional supplements. Furthermore, BMP enhanced functional properties such as water and oil absorption indexes and solubility, whereas inulin increased swelling power and both ingredients decreased viscosity and syneresis. Overall, the results indicated that such blends may be useful in functional gluten-free bakery products (such as bread, cookies, and cakes) for the benefit of celiac patients according to their functional and syneresis characteristics.

\section{Acknowledgements}

We would like to thank the Priority Academic Program Development of Jiangsu Province, Higher Education Institutes, Wuxi city, Jiangsu Province, China. We also extend our sincere gratitude to all the staff and students of the Research Center of Convenient Food and Quality Control. 


\section{Conflict of Interest}

We do not have any conflict of interest.

\section{References}

[1] Matos, M. E., and Rosell, C. M.. Understanding gluten-free dough for reaching breads with physical quality and nutritional balance. $J$. Sci. Food Agric. 95: 653-661. 2015.

[2] Shittu, T.A., Raji, A.O. and Sanni, A.O. Effect of baking time on some physical properties of bread loaf. Food Res Int. 40 (2): 280290. 2007.

[3] Ramesh, Y. A.. Rheological and functional properties of potato and sweet potato flour and evaluation of its application in some selected food products. Food Technological Research Institude, Mysore - 570020, India. 2005.

[4] Ghahremani-Majd, H. and Dashti, F. Chemical composition and antioxidant properties of cultivated button mushrooms (Agaricus bisporus). Horticulture, Environment, and Biotechnology, 56: 376-382. 2015.

[5] Shoaib, M., Shehzad, A., Omer, M., Rakha, A., Raza, H., Sharif, H. R., Shakeel, A. and et al. Review on inulin properties, health benefits and food applications. Carbohydrate Polymers, 147: 444-454. 2016

[6] Saeed, S., Muhammad, M. A., Humaira, K., Saima, P., Sharoon, M. and Abdus, S. Effect of sweet potato flour on quality of cookies. Journal Agriculture Resources, 50 (4). 2012.

[7] Okafor, J. N. C., Okafor, G. I., Ozumba, A. U. \& Elemo, G. N. Quality characteristics of bread made from wheat and Nigerian oyster mushroom (Pleurotus plumonarius) powder. . Pakistan Journal of Nutrition, 11(1): 5-10. 2012.

[8] Franco, T.S., Perussello, C.A., Elledersen, L.D.S.N. and Masson, M.L. Effect of process parameters on foam mat drying kinetics of yacon (Smallanthus sonchifolius) and thin-layer drying modeling of experimental data. J. Food Process Eng. 2015.

[9] Pop, O.L., Vodnar, D.C., Suharoschi, R., Mudura, E. \& Socaciu, C. L. plantarum ATCC 8014 entrapment with prebiotics and lucerne green juice and their behavior in simulated gastrointestinal conditions. J. Food Process Eng. 2015.

[10] Kaur, M. and Singh, N. Relationships between selected properties of seeds, flours, and starches from different chickpea cultivars. Int. J. Food Prop. 9:597- 608. 2006.

[11] Siddiq, M., Nasir, M., Ravi, R., Dolan, K. D. and Butt, M. S. Effect of defatted maize germ addition on the functional and textural properties of wheat flour. Int. J. Food Prop. 12: 860-870. 2009.

[12] AOAC. Official methods of analysis of AOAC International (19th ed.). Gaithersburg, MD, USA: AOAC International. 2012.

[13] Latimer, G. W. Official methods of analysis of AOAC International (18 ed.). Gaithersburg: EEUU. 2012.

[14] Huang, M., Liu, P., Song, S., Zhang, X., Hayat, K., Xia, S. and Gu, F. Contribution of sulfur-containing compounds to the colour inhibiting effect and improved antioxidant activity of Maillard reaction products of soybean protein hydrolysates. J.Sci Food Agric. 91: 710-720. 2011.

[15] AOAC. Official Methods of Analysis, (18th ed.). Association of Official Analytical Chemists, Washington, DC. 2006

[16] Maninder, K., Kawaljit, S. S. and Narpinder, S. Comparative study of functional, thermal and pasting properties of flours from different field pea and pigeon pea cultivars. Food Chemistry, 104: 259-267. 2007.

[17] Mebpa, H. D., Eboh, L. and Nwaojigwa, S. U. Chemical composition, functional and baking properties of wheat-plantain composite flour. Afric. J. Food Agric. Develop. 7(1):1-22. 2007.

[18] Beuchat, L. R. Functional and electrophoretic characteristic of succinylated peanut flour. J. Agricult. Food Chem. 25: 258-261. 1977.

[19] Crosbie, G. B. The relationship between starch swelling properties, paste viscosity, and boiled noodle quality in wheat flours. $J$. Cereal Sci. 13:145-150. 1991.
[20] Kuar, L., Singh, N. and Sodhi, S. N. Some properties of potatoes and their starches II. Morphological, thermal and rheological properties of starches. Food Chemistry, 79:183-192. 2002.

[21] Uju, N. L. and Obiakor-Okeke, P.N. Nutritional Profile of Three Different Mushroom Varieties Consumed in Amaifeke, Orlu Local Government Area, Imo State, Nigeria. Food Science and Quality Management, 31: 70-77. 2014.

[22] Ojo, M. O., Ariahu, C. C. and Chinma, E. C. Proximate, Functional and Pasting Properties of Cassava Starch and Mushroom (Pleurotus Pulmonarius) Flour Blends. American Journal of Food Science and Technology, 5(1): 11-18. 2017.

[23] Aishah, M. S. and Wan Rosli, W. I. Effect of Different Drying Techniques on the Nutritional Values of Oyster Mushroom (Pleurotus sajor-caju). Sains Malaysiana, 42(7): 937-941. 2013.

[24] Jeong, S.C., Jeong, Y.T., Yang, B.K., Islam, R., Koyyalamudi, S.R., Pang, G., Cho, K.Y. and Song, C.H. White button mushroom (Agaricus bisporus) lowers blood glucose and cholesterol levels in diabetic and hyper cholesterolemic rats. Nutrition Research, 30: 49-56. 2010.

[25] Ekunseitan, O; Obadina, A. O; Sobukola, O. P; Omemu, A. M; Adegunwa, M. O. and et al. Nutritional composition, functional and pasting properties of wheat, mushroom, and high quality cassava composite flour. J Food Process Preserv. 1-8. 2016.

[26] Pazianas, M., Pazianas, M., Butcher, G.P., Subhani, J.M., Finch, P.J., Ang, L., Collins, C., Heaney, R.P., Zaidi, M. and Maxwell, J. D. Calcium absorption and bone mineral density in celiac after long term treatment with gluten-free diet and adequate calcium intake. Osteoporosis International, 16 (1): 56-63. 2005.

[27] Ohlund, K., Olsson, C., Hernell, O. and Ohlund, I. Dietary shortcomings in children on a gluten-free diet. Journal of Human Nutrition and Dietetics, 23 (3): 294 - 300. 2010.

[28] Mustapha, S., Mohammed, U. M., Adeosun, N. O., Mathew, T. J., Muhammed, S. S.and Ibn-Aliyu, A. Nutritional and Functional Characterization of Undecorticated Groundnut (Arachis hypogaea L.) Seeds from Bosso Market, Minna, Nigeria. American Journal of Food Science and Technology, 3(5): 126-131. 2015.

[29] Yadav, B. S., Yadav, R. B., Kumari, M. and Khatkar, B. S. Studies on suitability of wheat flour blends with sweet potato, colocasia and water chestnut flours for noodle making. LWT - Food Science and Technology, 57: 352-358. 2014.

[30] Chan, H.T., Bhat, R. and Karim, A.A. Physicochemical and Functional Properties of Ozone-Oxidized Starch. J. Agric. Food Chem. 57: 5965-5970. 2009.

[31] Kaur, A., Singh, N., Ezekiel, R. and Guraya, S. H. Physicochemical, thermal and pasting properties of starches separated from potato cultivars grown at different locations. Food Chemistry, 101: 643-651. 2007.

[32] Kim, D. N., Bae, I. Y., Inglett, G. E. and Lee, S. Effect of hydrothermal treatment on the physicochemical, rheological and oil-resistant properties of rice flour. Journal of Texture Studies, 40 : 192-207. 2009.

[33] Tester, R.F. and Morrison, W.R. Swelling and gelatinization of cereal starches. 1. Effects of amylopectin, amylose, and lipids. Cereal Chemistry, 67:551-557. 1990.

[34] Batey, I. L. and Curtin, B. M. The effects on the pasting viscosity of starch and flour of different operating conditions for the Rapid Visco Analyzer. Cereal Chem. 77: 754-760. 2000.

[35] Lee, J.H., Cho, A.R., Hong, J.Y., Park, D.-J. and Lim, S.-T. Physical properties of wheat flour composites dry-coated with micro articulated soybean hulls and rice flour and their use for low-fat preparation. J. Cereal Sci. 63: 636 - 643. 2012.

[36] Charoenrein, S. and Preechathammawong, N. Effect of waxy rice flour and cassava starch on freeze-thaw stability of rice starch gels. Carbohydrate Polymers, 90: 1032-1037. 2012.

[37] Luh, B. S. Rice products. In C. Y. W. Ang, K. Liu, and Y. W. Huang (Eds.), Asian foods: science and technology (pp. 5-42). 1999. Lancaster, PA: Technomic Publishing.

[38] Ribotta, P. D., Colombo, A., León, A. E. and Añón, M. C. Effects of soy protein on physical and rheological properties of wheat starch. Starch, 59:614 - 623. 2007.

[39] Arunyanart, T. and Charoenrein, S. Effect of sucrose on the freeze-thaw stability of rice starch gels: Correlation with microstructure and freezable water. Carbohydrate Polymers, 74: 514-518. 2008. 